Канд. техн. наук А.Л. Обухова

Cand. of techn. sciences A.L. Obukhova

\title{
ПИТАННЯ ПРІОРИТЕТУ ДЛЯ ПАСАЖИРСЬКИХ ТА ВАНТАЖНИХ ПОЇЗДІВ ПРИ ЗМІШАНОМУ РУСІ
}

\section{QUESTION PRIORITY FOR PASSENGER AND FREIGHT TRAINS IN MIXED MOVEMENT}

\author{
Представив д-р техн. наук, професор Д.В. Ломотько
}

\begin{abstract}
Вступ. Транспортна галузь $\epsilon$ складною структурою, для ефективного функціонування якої необхідно враховувати велику різноманітність як внутрішніх факторів, так i зовнішніх. Залізничний транспорт, будучи конкурентним середовищем, серед зовнішніх факторів повинен, безумовно, орієнтуватися на споживачів своїх послуг пасажирів i вантажовласників. Споживчі інтереси, інноваційні процеси, міжнародна орієнтація визначають напрямок розвитку та вдосконалення роботи залізниці.
\end{abstract}

I одним 3 таких шляхів $\epsilon$ впровадження і розвиток швидкісного руху. Швидкість доставки - це один з факторів, на який орієнтуються всі споживачі послуг транспорту. Будь то пасажири, які прагнуть як можна швидше прибути на місце призначення, або вантажовласники, у фінансових інтересах яких, щоб вантаж швидко був доставлений до станції призначення.

Активна модернізація, оновлення техніки, технологій, інфраструктури заходи, необхідні для розвитку швидкісного пасажирського руху в Україні. У 2011 році на кількох напрямках, що пов'язують великі міста, почали курсувати поїзди, наявність яких дає змогу заявити, що в Україні 3'явився швидкісний рух. Однак, чи таким вже позитивним виявився цей досвід.
Постановка проблеми. Незважаючи на єдину структуру управління, вантажне i пасажирське сполучення завжди були конкуруючим середовищем всередині транспортної галузі. Зазвичай пасажирські перевезення привертають більшу увагу, маючи пріоритет як в експлуатаційній роботі, так і в інвестиціях 3 дуже простої причини - тому що пасажири проти вантажних перевезень. Уряд і громадська думка більш зацікавлені в задоволенні потреб сотень мільйонів пасажирів магістральних i приміських ліній, ніж потреб декількох тисяч вантажовласників. Залізниці зі змішаним рухом змушені миритися 3 пріоритетом пасажирських перевезень у всіх сферах діяльності, хоча досвід показує, що, всупереч усьому, вантажні перевезення розвиваються швидше, крім випадків дуже великих капіталовкладень у пасажирські перевезення (наприклад, у нові високошвидкісні лініі). Тому питання розмежування пасажирського та вантажного руху є актуальним.

Аналіз останніх досліджень і публікацій. Розвиток залізничних перевезень за останні десятиліття показує, що залізниці зі змішаним рухом відчувають труднощі у розвитку обох видів перевезень. Японія $є$ найбільш типовим прикладом створення високошвидкісних пасажирських ліній загальною протяжністю 2000 км на 
шкоду звичайним пасажирським i вантажним. Після 25 років експлуатації швидкісної мережі Сінкансен обсяг пасажирських перевезень насилу утримується на досягнутому рівні, а вигоди від високошвидкісних ліній компенсували втрати від скорочення числа користувачів звичайними залізницями. Щодо вантажних перевезень, і до того незначних, то їх обсяг скоротився наполовину. Більше того, великий обсяг інвестицій призвів до занепаду залізниць країни під тягарем боргів, що накопичилися. Після відділення від пасажирських вантажні перевезення перебувають у кризовому стані i виживають лише за рахунок перевезень маршрутними поїздами і змішаними.

У Європі, де залізниці приступили до освоєння високошвидкісного руху через 15 20 років після Японії, ситуація не настільки драматична, але простежується та сама тенденція. Обсяг пасажирських перевезень, які отримували переважні інвестиції, зростав повільно, а вантажних перевезень за браком інвестицій або стабілізувався, або скоротився, за винятком кількох залізниць, де вони мають пріоритет.

Залізниці Китаю є єдиними зі змішаним рухом, де зниження обсягу вантажних перевезень не було. Уряд зажадав, щоб у всіх сферах діяльності залізниць пріоритет віддавався вантажним перевезенням, особливо вугілля, на якому тримається вся енергетика i народне господарство в цілому. В Індії ж, навпаки, подібно Японії і Європі, дилема вантажних і пасажирських перевезень вирішується на користь останніх.

У США, Канаді, Південній Америці, Австралії і на півдні Африки зростання обсягу вантажних перевезень не припинявся, тому що в них зацікавлена більшість залізниць. Щорічне зростання на $5 \%$ протягом останніх 15 років забезпечується, головним чином, завдяки різкому підвищенню продуктивності за рахунок залучення відправників масових вантажів [1].
Умови питання розмежування маршрутів вантажних i пасажирських поїздів були актуальними як в часи Радянського Союзу, так залишаються наявними i на території України. Тому розвитку теорії та практики технології перевізного процесу, а саме процесу взаємодії та взаємозалежності пасажирського i вантажного руху, приділяли увагу такі вчені та практики: Аветикян М.А., Бутько Т.В., Галабурда В.Г., Дерибас А.Т., Дьяков Ю.В., Ж Жуковицький I.В., Кірпа Г.М., Куренков П.В., Нагорний Є.В., Негрей В.Я., Повороженко В.В., Поляков А.О., Резер С.М., Самсонкин B.M., Смехов А.O., Ходаківський О.М., Шибаєв О.Г., Яновський П.О. та інші.

В умовах державного регулювання тарифів та утримання їх на рівнях, однозначно нижчих за собівартість, всі види пасажирських перевезень, крім міжнародних, $є$ збитковими. Таким чином, виходить, що основна частка прибутку припадає на роботу вантажних перевезень, у той час як пріоритетність у прямуванні за маршрутом віддається пасажирським поїздам. А при збільшенні співвідношення швидкості ходу пасажирських поїздів до швидкості вантажних має місце зростання затримок поїздів на проміжних станціях під обгоном пасажирськими через неідентичність графіка руху (див. рисунок) [2].

У 90-ті роки особливо великі надії в Україні та інших східноєвропейських країнах пов'язували 3 міжнародними транспортними коридорами (МТК). На конференції, що проходила в Афінах у жовтні 1996 року, в програму TRACECA (Transport Corridor Europed Caucaus Asia транспортний коридор Європа - Кавказ Азія) була включена Україна [3].

Через територію України проходило кілька транспортних коридорів, маршрут прямування яких пролягав по основних напрямках - Захід-Схід і з виходом у порти Одеси та Іллічівська. 
Мета статті. На даному етапі експлуатації залізничних магістралей виходить, що основні напрямки залізничної мережі України охоплені пріоритетними маршрутами як вантажних, так i пасажирських поїздів. Причому i в першому, i в другому, випадку визначальним чинником $\epsilon$ термін перебування в дорозі - вантажів або пасажирів. При цьому $\epsilon$ ще чимала кількість звичайних поїздів. Тобто йде зіткнення інтересів пасажирів i вантажовласників, яке вирішується в бік пасажирських перевезень, хоча 3 фінансового боку, окупність перевезень загалом забезпечується за рахунок перевезень вантажів. Тому метою даної статті є розгляд шляхів вирішення питання розмежування пасажирського та вантажного руху.

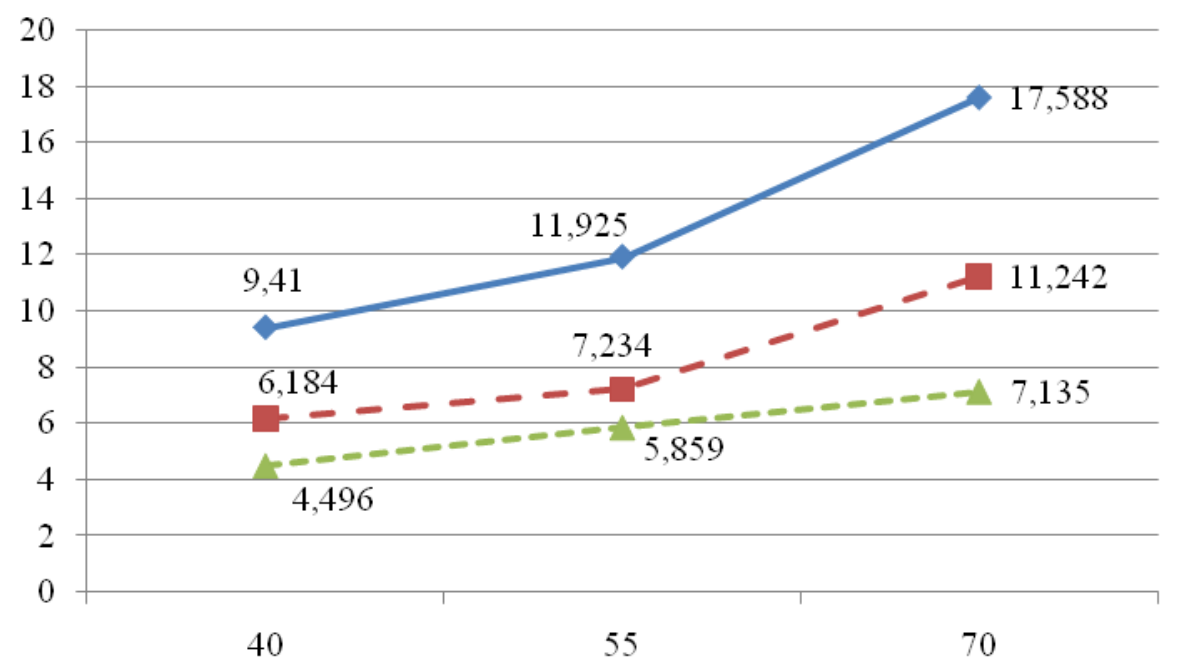

Рис. Середній час стоянок на станціях залежно від кількості довгосоставних поїздів на ділянці при співвідношенні швидкості ходу вантажного та пасажирського поїзда

Виклад основного матеріалу. Враховуючи відмінності в категоріях поїздів, які переміщуються по одній дільниці, ставляться особливі вимоги до розрахунку як наявної, так і потрібної пропускних спроможностей залізничних дільниць.

Проте сама наявна пропускна спроможність залізничних ділянок не дає достатньо повної оцінки параметрів функціонування лінії, що впливають на якість перевізного процесу. Найбільш загальною характеристикою такої оцінки виступає рівень використання пропускної спроможності (коефіцієнт завантаження), що дозволяе визначити умови функціонування конкретних залізничних дільниць і цілих напрямків.
Точна оцінка рівня використання наявної пропускної спроможності залізничних дільниць та напрямків $\epsilon$ фундаментальною основою для вирішення найважливіших експлуатаційних задач оперативного і стратегічного характеру. До числа таких завдань слід віднести:

- оперативне планування напрямів прямування поїздо- і вагонопотоків;

- розрахунки планів формування вантажних поїздів;

- планування капітальних вкладень у розвиток залізничних дільниць 3 метою нарощування їх пропускної i провізної спроможності;

- оцінка доцільності спеціалізації залізничних ліній за видами руху (вантажний, пасажирський). 
При визначенні наявної пропускної спроможності, для вантажного руху або сумарної наведеної потрібної пропускної спроможності користуються коефіцієнтами знімання. Цей коефіцієнт показує, скільки вантажних поїздів (або пар поїздів) знімається 3 максимального графіка одним пасажирським поїздом (або парою поїздів). Знімання поїздів виходить внаслідок того, що частина пропускної спроможності дільниці при нормальному графіку займається пасажирськими поїздами і тому число вантажних поїздів виходить менше [4].

У загальному випадку прийнято вважати, що можлива пропускна спроможність залізничної дільниці по перегонах визначається максимальним числом вантажних поїздів (пар поїздів) встановлених ваги i довжини. Можлива провізна спроможність - це кількість тонн вантажу, що може бути пропущено або перевезено по дільниці в одиницю часу (доба, година) за даної технічної оснащеності i прийнятого способу організації руху поїздів.

Можлива пропускна спроможність залізниці залежить від числа головних колій, способу організації руху поїздів (прийнятого типу графіка руху), часу ходу поїздів по перегону, станційних i міжпоїзних інтервалів.

Розрахунок можливої пропускної спроможності дільниці по вантажному руху $\left(N_{\text {гp}}\right)$ на розрахункові роки $2,5,10,15$

$N_{\text {гp } 2,5,10,15}=\gamma N_{\max }-\left(\varepsilon_{n c} N_{n c}+\varepsilon_{c \sigma} N_{c \sigma}\right)$

де $\gamma$ - коефіцієнт заповнення пропускної спроможності ділянок по перегонах;

$\varepsilon_{n c}, \varepsilon_{c \sigma}-$ коефіцієнти знімання, що показують, скільки пар вантажних поїздів знімає одна пара пасажирських і збірних поїздів;

$N_{n c}, N_{c \sigma}$ - число пар пасажирських i збірних поїздів на добу, що приймається на розрахункові роки.
Частина коефіцієнта знімання, не залежного від колійного розвитку $\varepsilon_{n c}^{H}$, складається 3 коефіцієнта основного знімання $\varepsilon_{o}$ i коефіцієнта додаткового знімання $\varepsilon_{\partial}$

$$
\varepsilon_{n c}^{H}=\varepsilon_{o}+\varepsilon_{\partial}
$$

Коефіцієнт основного знімання залежить від часу ходу вантажного i пасажирського поїздів по дільниці i обмежуючому перегону, а також від взаємного розташування пасажирських поїздів на графіку руху поїздів.

Коефіцієнт додаткового знімання виникає при некратності періоду між зонами знімання суміжних пасажирських поїздів міжпоїзного інтервалу [5, 6].

На величину коефіцієнтів знімання впливають:

1) співвідношення швидкостей руху поїздів різних категорій;

2) кількість пасажирських поїздів;

3) кількість прискорених вантажних поїздів, які мають перевагу перед іншими поїздами;

4) неідентичність перегонів;

5) колійний розвиток проміжних станцій;

6) тип графіка руху поїздів.

Iз вищесказаного випливає, що пріоритетність у переміщенні за маршрутом щодо вантажного руху, є тільки у прискорених поїздів. Решта категорій вантажних поїздів мають поступатися щодо переваги в прямуванні по дільниці пасажирським поїздам.

Таким чином, підвищення потужності залізниці може здійснюватися в такій послідовності:

а) зміна графіка руху поїздів;

б) зміна локомотива на більш потужний;

в) зміна способу організації руху поїздів;

г) застосування посиленої тяги;

д) електрифікація лінії; 

колій.

е) часткове укладання другої колії;

ж) будівництво суцільних других

Повне розмежування пасажирського та вантажного руху - це процес, що потребує значних витрат часу та матеріальних коштів. Тому більш виправданим буде встановлення пріоритетності напрямків курсування пасажирських поїздів 3 метою максимально можливого вивільнення їх від вантажного руху та переведення вантажних поїздів на інші (паралельні) напрямки. Це дозволить застосувати для кожного виду перевезення оптимальне технічне обладнання, зменшити обсяги інвестицій у реконструкцію інфраструктури, підвищити швидкості руху та скоротити витрати на утримання колії в процесі експлуатації.

Висновки. Вихід із ситуації, що формувалася роками, може бути в поділі руху пасажирських і вантажних поїздів, тобто виділенні окремих залізничних колій для руху переважно пасажирських або вантажних поїздів.

Відповідно до прийнятої в країнах Європи та СНД практики рух пасажирських поїздів зі швидкістю до 140 км/год може відбуватися на існуючих лініях поруч 3 вантажним рухом. У той же час дільниці, призначені для пропуску швидкісних поїздів зі швидкістю від 161 до 200 км/год, мають, як правило, звільнятися від вантажного руху для запобігання руйнування головної колії через надзвичайне навантаження на неї.

Таким чином, розділення пасажирського та вантажного руху рішення не тільки вимушене, а й цілком економічно виправдане. При швидкісному русі пасажирських поїздів більш інтенсивно використовується рухомий склад, зменшується потреба в капіталовкладеннях на його придбання, зменшуються витрати на утримання інфраструктури з урахуванням швидкісного та великовагового руху, які мало сумісні. Використання залізничної колії окремо для руху пасажирських поїздів зменшує витрати на iii ремонт і утримання. Така колія може служити без капітальної модернізації до 18 років, тоді як на справжніх змішаних коліях ремонт необхідно проводити кожні 4-5 років.

Теоретичний характер висновків вказує на необхідність подальших досліджень та розрахунків за темою.

\section{Список літератури}

1. Мировые тенденции в грузовых перевозках $=$ Generale des Chemins [Электронный pecypc] // Transport.ru: отраслевой портал. - Режим доступа: http://www.transport.ru/2_period/rail/97_05/2.htm.

2. Фуфачева, М.В. Развитие методов этапного овладения перевозками на двухпутных линиях при обращении длинносоставных грузовых поездов [Текст]: автореф. дис. ... канд. техн. наук: 05.22.08: защищена 18.08.10 / М.В. Фуфачева; [Ур. гос. ун-т путей сообщ.]. Иркутск, 2010. - 21 с.

3. Дергаусов, М. Международные транспортные коридоры и Украина [Текст] / М. Дергаусов // Восток (Oriens). - 2002. - № 1 (44). - С. 13-17.

4. Технический железнодорожный словарь [Текст]: Государственное транспортное железнодорожное издательство / Н.Н. Васильев, О.Н. Исаакян, Н.О. Рогинский, Я.Б. Смолянский, В.А. Сокович, Т.С. Хачатуров. - М.: Транспорт, 1961. -560 с.

5. Грунтов, П.С. Управление эксплуатационной работой и качеством перевозок на железнодорожном транспорте [Текст] / П.С. Грунтов, Ю.В. Дьяков, А.М. Макарочкин [и др.]; под ред. П.С. Грунтова. - М.: Транспорт, 1994. - 543 с. 
6. Кудрявцев, В.А. Организация управления движением на железнодорожном транспорте [Текст] / В.А. Кудрявцев, В.И. Бадах, К.А. Белов [и др.]; под ред. В.А. Кудрявцева. - М.: Издательский центр «Академия», 2006. - 432 с.

Ключові слова: пасажирське сполучення, вантажне сполучення, пропускна спроможність, коефіцієнт знімання.

\section{Анотаціï}

Залізниці зі змішаним рухом змушені миритися з пріоритетом пасажирських перевезень у всіх сферах діяльності, хоча досвід показує, що вантажні перевезення розвиваються швидше. У даній статті розглянуті недоліки спільного використання напрямків під вантажний i пасажирський рух i перспективи розмежування маршрутів вантажних $\mathrm{i}$ пасажирських поїздів.

Железные дороги со смешанным движением вынуждены мириться с приоритетом пассажирских перевозок во всех областях деятельности, хотя опыт показывает, что грузовые перевозки развиваются быстрее. В данной статье рассмотрены недостатки совместного использования направлений под грузовое и пассажирское движение и перспективы размежевания маршрутов грузовых и пассажирских поездов.

Railways mixed traffic to contend with the priority of passenger traffic in all areas, although experience shows that freight develop faster. This article describes the drawbacks of sharing destinations for cargo and passenger traffic and prospects demarcation route freight and passenger trains. 